\title{
STUDENTS' RESPONSES TOWARDS THE USE OF LANGUAGE INSTRUCTIONS BY LECTURERS IN EAP CLASSROOMS
}

\author{
Amanda Pradhani Yanwar \\ Universitas Bojonegoro \\ amandapradhani2@gmail.com
}

\begin{abstract}
This research was aimed to describe the students' responses toward the use of language instructions. It was conducted at Unit Pelaksana Teknis Bahasa, Universitas Sebelas Maret, Surakarta, Indonesia. The techniques for collecting the data used in this research were observation, interview, document analysis, and questionnaire. Based on the analysis of the data, it can be concluded that the students could interact with the lecturer when the lecturer used both English and Indonesian language during the teaching and learning process. Therefore, it is recommended for English lecturers to use language instructions properly to make the students understand more about what the lecturer is talking about, to make the students accustomed more about the use of English vocabularies, to make the lecturers and the students have an enjoyable and successful English teaching and learning process. For the other researchers who want to conduct similar research, the result of this research can be an additional reference.
\end{abstract}

Keywords: Students' responses, language instructions, lecturers, EAP classrooms

\section{A. INTRODUCTION}

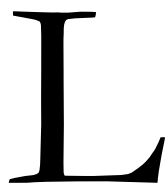

anguage is an important aspect in education. Language is not everything in education, but without language, everything is nothing in education (Wolff, 2005, p. 3). Although language is not everything in education, it is a root for multilingual societies because of the impact on educational success (Ewie \& Eshun, 2015, p. 72).

Nowadays, English is one of the most important languages in the world. It is the bridge language that can make people easier in communicating each other. The effect of the use of English in educational contexts is that English is tended to be used as a medium of instruction in the classroom although the people use their local language (Vu \& Burns, 2014, p. 2).

In education field, the students learn English since in kindergarten. They start learning English from the simplest part to the most complicated one. Most of the students are not interested in learning English because they think that English is difficult. The students with negative learning attitudes can have anxiety in the learning process; they will be bored easily and have difficulties to enjoy the learning process (Zulfikar, et al., 2019, p. 2). Besides, the students can be bored in the language learning process because of teachers' ineffective approaches. The teacher only explained the materials without asking about the students' participation. That made the class really boring (Zulfikar, et al., 2019, p. 2).

In teaching English, the lecturers use many strategies so that the students can be more interested in learning English. One of the strategies is by using the target and first language instruction. Language instructions have an essential role toward the students' academic 
performance (Kagwesage, 2012, p. 1). Language instructions have an important role to make sure effective communication happened during the teaching and learning process (Ewie \& Eshun, 2015, p. 73). In addition, language instructions are essential aspects of quality of education in terms of the process happened during the teaching and learning process (Telli, 2014, p. 13).

During the teaching and learning process, the lecturers use the target and first language instruction. So, it can help the students to understand more about the delivered materials. Besides, the lecturers have to know more which aspects are more appropriate used by the target or first language instruction. Dickson (1996) stated that there were nine aspects of teaching that should be used in the target language: organizing activities, directing pupils, asking questions, setting homework, commenting on work, teaching grammar, disciplining pupils, correcting mistakes, and teaching grammar. In addition, Franklin (1990) contended that there were eight aspects of teaching that should be used in the target language: correcting written work, organizing classroom, explaining lesson, disciplining pupils, explaining meaning, giving activity instructions, explaining grammar, and chatting informally with pupils. On the other hand, there were some aspects mentioned that are more suitable used in the students' first language, such as: teaching grammar, explaining lesson, and explaining meaning. The lecturers have to use suitable language in teaching English for certain aspects. Thus, this study was aimed to investigate the students' responses towards the use of language instructions.

\section{B. REVIEW OF LITERATURE}

In EFL classrooms, the use of language instructions has an important role to create successful teaching and learning process. The students will keep motivated in learning English if the lecturers use the target and first language instructions. The language instructions have an essential role in education field to create success in fulfilling the objectives and to help the students to realize their human rights (Chavez, 2016, p. 189).

In EFL classroom, if the lecturers can create balanced teaching and learning process about the use of English and the students' first language, the students can enjoy more in learning English. Zulfah, et al., (2015) stated that the use of English and the first language has points in EFL classrooms. The suitable use of English and the first language does not only give more language input to the students, but also motivate the students to learn English more. Besides that, the use of the first language has a supportive role in teaching English as a foreign language (Zulfah, et al., 2015, p. 1281). The use of the first language is one of the simplest strategies to make the students understand more about difficult expressions (Shin, 
2006, p. 6). The use of the first language can make the students feel relaxed and avoid anxiety or confusion about English (Ford, 2009, p. 77).

Furthermore, there were two previous studies related to this research. First of all, it was from Nilsson (2013) entitled "Target Language in the Primary Classrooms." The study found that the participants used mostly in English to dominate their approaches, which was about $75 \%$ in the group as a whole. The participants used some strategies and techniques to support students' comprehension in the target language. Besides, the participants used the first language to help the students with the clearer comprehension, explanations, and procedural instructions and discipline the students.

There were similarity and differences between Nilsson's research and this research. There was only one similarity. Those two researches wanted to find out the use of language instructions in EFL classroom. On the other hand, there were two differences between this research and Nilsson's research. First, Nilsson's research was done in primary classrooms, while this research was done in EAP classrooms (UPT Babasa, Universitas Sebelas Maret). Second, this research wanted to find out the students' responses towards the use of language instructions by lecturers in EAP classrooms, while Nilsson did not do it for his research.

The second one, it was from Miettinen (2009) entitled "As much English as possible: A study on two secondary school English teachers' language use and the motives behind their language choices." This study found that an experienced English teacher who used the target language all the time only gave very few single-word translations in Finnish. On the other hand, the other participant who was an inexperienced substitute teacher only used mostly in English in the beginning of the lesson and switched to the first language exclusively in the middle of the lesson, resulted in average of $47 \%$ of using the target language. Although the participants stressed the importance of using the target language, they did not want to avoid the use of the first language in EFL classroom. In fact, they used the first language to teach grammar and discipline the students.

There were some similarities and differences between this research and Miettinen's research. There were two similarities: 1) those two researches wanted to find out various language instructions used by teachers in EFL classroom, 2) those researches wanted to find out aspects of language instructions used in EFL classroom. On the other hand, there were two differences between Miettinen's research and this research. First, Miettinen did his research on two secondary schools, while this research was done at UPT Bahasa, Universitas Sebelas Maret. Second, this research wanted to find out the students' responses towards the 
use of language instructions by lecturers in EAP classrooms, while Miettinen did not do it on his research.

\section{METHOD}

This research was conducted at UPT Bahasa (Unit Pelaksana Teknis Bahasa), Universitas Sebelas Maret. It is located at J1. Ir. Sutami No. 36A, Jebres, Surakarta, Central Java, Indonesia. The subjects of this research were the master students of three EAP classrooms at UPT Bahasa, Universitas Sebelas Maret. Those students were observed eight times. The reason why the researcher chose EAP classrooms at UPT Bahasa, Universitas Sebelas Maret was because it provided EAP classrooms for master students.

The design of this research is a case study. A case study investigates a contemporary phenomenon in the context of real world, especially when the boundaries between phenomenon and context may not be clear. (Yin, 2014, p. 2). In addition, among the variations in case studies, a case study can include single or multiple cases, can be limited to quantitative evidence, and can be a useful method in doing an evaluation (Yin, 2014, p. 2). In this research, the research belonged to a single and intrinsic case study. It means that the research only focused on the students' responses towards the use of language instructions by lecturers in EAP classrooms.

In conducting this research, the researcher gained the data from three sources: informants, events, and documents. Those sources will be described below.

\section{Informants}

The informants were the participants of this research. The researcher chose the students consisting of the low, medium, and high students to be interviewed, but she took all students coming from EAP C26, EAP C07, and EAP C14 to be observed and given the questionnaire. The students were observed eight times. The researcher used the master students in EAP classrooms as the informants because she would like to know more about the students' responses towards the use of language instructions during the activities in the classrooms.

\section{Event}

The event of this research was the use of the lecturers' language instructions during the teaching and learning process. The researcher got the data of the students' responses towards the use of language instructions during the activities in the classrooms.

\section{Document}

There were two documents used in this research: transcript of the questionnaire and transcript of the interview. In the transcript of the questionnaire, the researcher put the 
students' responses towards the lecturers' use of language instructions in the form of percentages. In addition, in the transcript of the interview, the researcher the low, medium, and high students' opinions related to the use of language instructions in EAP classrooms.

In this research, there were three techniques used to collect the data. Those techniques will be described below.

\section{Interview}

The researcher interviewed nine master students consisting of the low, medium, and high students. To get the appropriate students, the researcher asked the lecturers to choose three students consisting of the low, medium, and high students. The researcher had open interview with those participants. It meant that the participants would have unlimited explanations in answering the questions. The researcher had eight questions for the students to get more complete information. The questions could be developed during the interview session. In interviewing the students, the researcher would like to identify their opinions about the necessity of using language instructions during the teaching and learning process, the advantages of the use of language instructions for their understanding of the materials and building good relationship with the lecturers.

\section{Document Analysis}

In this research, the researcher used two documents. They were transcript of the questionnaire and transcript of the interview.

\section{Questionnaire}

The questionnaire was given to all master students coming from three EAP classrooms namely EAP C26, EAP C07, and EAP C14. The questionnaire was used to reveal the students ${ }^{\text {ee }}$ responses towards the use of language instructions affecting their understanding of materials. The questionnaire was also used to gain more complete data and support the data coming from interview. The students would give a checklist $(V)$ to each item of the statement in the questionnaire based on Likert scale ranging from 1 (Strongly Disagree), 2 (Disagree), 3 (Agree), and 4 (Strongly Agree).

The questionnaire was about the students' responses towards the lecturers' use of language instructions. It contained aspects of language instructions consisting of language, competence, and benefit of using language instructions in EAP classrooms. The aspect of 'language' consisted of using full English, having clear pronunciation, understanding English vocabularies, giving instructions, asking questions, commenting on work, and disciplining students. The aspect of 'competence' consisted of using Indonesian language, explaining the lessons, teaching grammar, explaining unfamiliar English vocabularies, explaining English 
reading texts and the questions, explaining how to write sentences and paragraphs, switching English into Indonesian sentences, mixing English with Indonesian vocabularies, and telling stories. The last, the aspect of 'benefit' consisted of being more interested and motivated in joining the learning process, understanding materials, having good atmosphere in the learning process, and having good relationship with the lecturer.

Furthermore, the researcher used methodological triangulation. It meant that the researcher used three different techniques in collecting the data: interview, document analysis, and questionnaire. The researcher would check the result of interview, document analysis, and questionnaire. Then, the researcher would obtain information whether the result coming from interview, document analysis, and questionnaire supported each other or not.

In addition, the researcher chose peer debriefing to verify the trustworthiness of the research because a peer debriefer could have other opinions about the meanings of the findings related to the students' responses towards the use of language instructions in EAP classrooms. This means that the peer debriefer could give critics, suggestions, and recommendations for the researcher's work. In this case, the researcher chose an English lecturer to become a peer debriefer to check the validity of the data.

In analyzing the data, the researcher used the flow model namely 'interactive model' which was proposed by Miles and Huberman (1994). There were three stages in using the flow model: data reduction, data display, and conclusion drawing/verification (Miles \& Huberman, 1994, p. 10). Those stages will be described below.

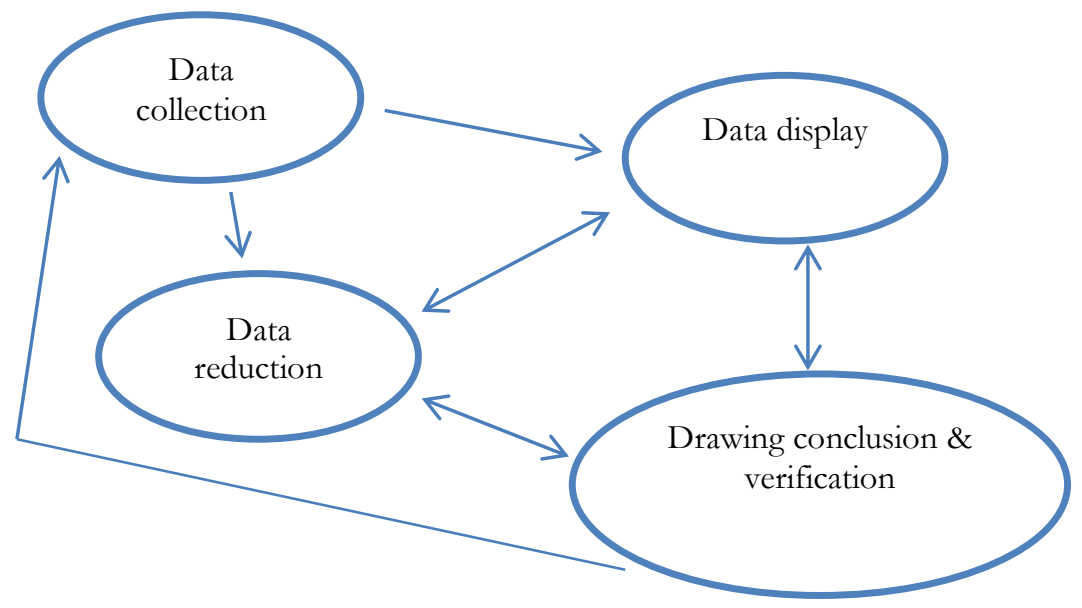

Figure 1. Flow Model (Miles \& Huberman, 1994, p. 10)

\section{Data Reduction}

Miles and Huberman (1994) contended that data reduction is the process of selecting, focusing, simplifying, abstracting, and transforming the 'raw' data that appear in the writtenup field notes. After collecting the data, the researcher reducted the data by focusing, 
selecting, and simplifying the data into the category of the students' responses towards the use of language instructions in EAP classrooms.

\section{Data Display}

A display is defined as an organized assembly of information that permits drawing conclusion and taking action. The most frequent form of the display in qualitative data is extended text (Miles \& Huberman, 1994, p. 11). It meant that in conducting the qualitative data, the researcher used words development as the data display. After focusing, selecting, and simplifying the data, the researcher displayed the result and discussion by describing and explaining the students' responses towards the use of language instructions in EAP classrooms in details, including tables and figures.

\section{Drawing Conclusion and Verification}

At the beginning in collecting the data, the qualitative researcher begins to decide what things mean and notes regularities, patterns, explanations, possible configurations, causal flows, and propositions. Final conclusions can be showed after finishing the data collection (Miles \& Huberman, 1994, p. 11). After collecting and analyzing the data, the researcher concluded what she had gotten during conducting the research. The researcher drew some conclusions and gave some suggestions related to the students' responses towards the use of language instructions in EAP classrooms.

\section{FINDINGS AND DISCUSSION}

\section{Findings}

The researcher gave questionnaire to the students to know more about their opinions related to the use of language instructions by the lecturers in EAP classroom. To get more details, it can be seen in the table below.

Table 1. Percentages of students' responses towards lecturers' use of language instructions

\begin{tabular}{|c|c|c|c|c|c|}
\hline No. & Aspects of Language Instructions & Studen & s' Respo & ises & \\
\hline A. & Language & SD & $\mathrm{D}$ & A & SA \\
\hline 1. & The use of full English in the classroom & $4.5 \%$ & $55.7 \%$ & $35.2 \%$ & $4.5 \%$ \\
\hline 2. & Very clear pronunciation & $1.1 \%$ & $3.4 \%$ & $68.2 \%$ & $27.3 \%$ \\
\hline 3. & Understanding English vocabularies & $0 \%$ & $14.8 \%$ & $77.3 \%$ & $8 \%$ \\
\hline 4. & Giving instructions in English & $0 \%$ & $21.6 \%$ & $71.6 \%$ & $6.8 \%$ \\
\hline 5. & Asking questions in English & $0 \%$ & $14.8 \%$ & $83 \%$ & $2.3 \%$ \\
\hline
\end{tabular}


Amanda Pradhani Yanwar, Students' Responses Towards...

\begin{tabular}{|c|c|c|c|c|c|}
\hline 6. & Commenting on work in English & $0 \%$ & $5.7 \%$ & $65.9 \%$ & $28.4 \%$ \\
\hline 7. & Disciplining students in English & $0 \%$ & $11.4 \%$ & $64.8 \%$ & $23.9 \%$ \\
\hline B. & Competence & SD & $\mathrm{D}$ & A & SA \\
\hline 1. & The use of Indonesian language in the classroom & & & & \\
\hline & & $1.1 . \%$ & $11.4 \%$ & $61.4 \%$ & $26.1 \%$ \\
\hline
\end{tabular}

2. Explaining the lessons like kinds of text, generic structure, and language features in Indonesian language

$0 \% \quad 11.4 \% \quad 68.2 \% \quad 20.5 \%$

3. Teaching grammar in Indonesian language

$1.1 . \% \quad 5.7 \% \quad 72.7 \% \quad 20.5 \%$

4. Explaining unfamiliar English vocabularies in Indonesian language

$2.3 \% \quad 6.8 \% \quad 67 \% \quad 23.9 \%$

5. Explaining English reading texts in Indonesian language

$1.1 . \% \quad 12.5 \% \quad 75 \% \quad 11.4 \%$

6. Explaining questions of reading texts in Indonesian language

$0 \% \quad 19.3 \% \quad 68.2 \%$

7. Explaining how to write sentences and paragraphs in Indonesian language

$0 \% \quad 12.5 \% \quad 71.6 \% \quad 15.9 \%$

8. Switching English sentences into Indonesian sentences

$0 \% \quad 5.7 \% \quad 58 \% \quad 36.4 \%$

9. Mixing English vocabularies with Indonesian vocabularies

$1.1 \% \quad 8 \% \quad 47.7 \% \quad 43.2 \%$

10. Telling stories in Indonesian language

C. Benefits

$\begin{array}{llll}4.5 \% & 22.7 \% & 56.8 \% & 15.9 \% \\ \text { SD } & \text { D } & \text { A } & \text { SA }\end{array}$

1. Being more interested in joining the learning process with the use of English and Indonesian language

2. Being more motivated in joining the learning process with the use of English and Indonesian $0 \% \quad 3.4 \% \quad 53.4 \% \quad 43.2 \%$ language

3. Understanding materials with the use of English and Indonesian language $0 \% \quad 2.3 \% \quad 58 \% \quad 39.8 \%$

4. Having good atmosphere in the learning process with the use of English and Indonesian language 


\begin{tabular}{llllll}
\hline 5. Having good relationship with the lecturer by & & & & \\
using English and Indonesian language & $0 \%$ & $3.4 \%$ & $61.4 \%$ & $35.2 \%$ \\
\hline
\end{tabular}

Based on the data of questionnaire, the students had some opinions about the use of language instructions. $35.2 \%$ of the students agreed when the lecturers used fully English during the teaching and learning process, but $55.7 \%$ of the students disagreed when the lecturers used fully English in the classroom. In addition, $68.2 \%$ of the students agreed that the lecturers had very clear pronunciation. Only 3.4\% of the students disagreed that the lecturers had very clear pronunciation. $77.3 \%$ of the students also agreed that they could understand English vocabularies used by the lecturers. In contrast, $14.8 \%$ of the students disagreed if they could understand English vocabularies used by the lecturers. In addition, $71.6 \%$ of the students agreed if the lecturers gave activity instructions in English, but $21.6 \%$ of the students disagreed if the lecturers gave activity instructions in English. 83\% of the students also agreed if the lecturers asked questions in English, but 14.8\% of the students disagreed if the lecturers asked questions in English. Moreover, $65.9 \%$ of the students agreed when the lecturers gave compliment for their work in English. Only 5.7\% of the students disagreed when the lecturers gave compliment in English. 64.8\% of the students agreed if the lecturers discipline the noisy students in English. On the other hand, 11.4\% of the students disagreed if the lecturers discipline the students by using English. Based on the finding, most of the students agreed that the lecturers used English in some aspects to make them getting more accustomed to the use of English.

Furthermore, the students had some opinions related to their language competence. $61.4 \%$ of the students agreed if the lecturers also used Indonesian language during the teaching and learning process, but $11.4 \%$ of the students disagreed if the lecturers used Indonesian language in the classroom. $68.2 \%$ of the students agreed if the lecturers explained the lessons like kinds of text including its generic structure and language features in Indonesian language, but $11.4 \%$ of the students disagreed if the lecturers explained the lesson by using Indonesian language. Besides, $72.7 \%$ of the students agreed that they could understand parts of grammar when the lecturers used Indonesian language, but 5.7\% of the students disagreed if they could understand parts of grammar when the lecturers used Indonesian language. $67 \%$ of the students also agreed that they could understand meanings of unfamiliar English vocabularies when the lecturers used Indonesian language. Only $6.8 \%$ of the students disagreed if they could understand meanings of unfamiliar English vocabularies when the lecturers used Indonesian language. In addition, $75 \%$ of the students agreed that 
they could understand the contents of English reading texts when the lecturers explained them in Indonesian language. In contrast, $12.5 \%$ of the students disagreed if they could understand the contents of English reading texts when the lecturers used Indonesian language. $68.2 \%$ of the students also agreed that they could answer the questions related to the reading texts when the lecturers explained them in Indonesian language. On the other hand, $19.3 \%$ of the students disagreed if they could answer the questions related to the reading texts when the lecturers used Indonesian language. Moreover, $71.6 \%$ of the students agreed that they could write good sentences and paragraphs when the lecturers used Indonesian language. Only $12.5 \%$ of the students disagreed that they could write good sentences and paragraphs if the lecturers used Indonesian language. $58 \%$ of the students also agreed that the lecturers switched English sentences into Indonesian sentences in the teaching and learning process. Only $5.7 \%$ of the students disagreed if the lecturers switched English sentences into Indonesian sentences in the classroom. In addition, $47.7 \%$ of the students agreed that the lecturers mixed English vocabularies with Indonesian vocabularies in sentences. Only $8 \%$ of the students disagreed if the lecturers mixed English vocabularies with Indonesian vocabularies in sentences. $56.8 \%$ of the students also agreed that the lecturers told stories in Indonesian language. In contrast, $22.7 \%$ of the students disagreed if the lecturers told stories by using Indonesian language. From the finding, most of the students agreed that the lecturers could use Indonesian language for some aspects so that the students could understand more about what the lecturers were explaining about.

Moreover, the students got some benefits during the teaching and learning process when the lecturers used both English and Indonesian language. 55.7\% of the students agreed that they were interested more in joining the teaching and learning process when the lecturers used both English and Indonesian language, but 5.7\% of the students disagreed if they were interested in joining the teaching and learning process when the lecturers used English and Indonesian language. Besides, $53.4 \%$ of the students agreed that they were motivated more to join the teaching and learning process when the lecturers used both English and Indonesian language. In contrast, $3.4 \%$ of the students disagreed if they were motivated when the lecturers used English and Indonesian language. In addition, 58\% of the students agreed that they could understand the materials well when the lecturers used both English and Indonesian language. Only $2.3 \%$ of the students disagreed if they could understand the materials when the lecturers used English and Indonesian language. 56.8\% of the students also agreed that they could have good atmosphere in learning process if the lecturers used both English and Indonesian language. Only $6.8 \%$ of the students disagreed if they could have good 
atmosphere when the lecturers used English and Indonesian language. In addition, 61.4\% of the students agreed that they could have good relationship with the lecturers when the lecturers used both English and Indonesian language in the classroom. On the other hand, $3.4 \%$ of the students disagreed if they could have good relationship with the lecturers when the lecturers used English and Indonesian language. Based on the finding, most of the students agreed that they got some benefits when the lecturers used both English and Indonesian language during the teaching and learning process.

During the observation, the researcher found that the students could interact with the lecturer when the lecturer used English and Indonesian language during the teaching and learning process. When the students did not respond or react towards what the lecturer was saying, the lecturer would switch English sentences into Indonesian sentences. Furthermore, the researcher got the other data from the students' interviews related to kinds of language instructions used by the lecturers in EAP classroom. The researcher interviewed three students from each EAP classroom consisting of low, medium, and high student. From the low student's point of views (DA), the researcher got the data as follow.

I like if the lecturer uses English and Indonesian language during the teaching and learning process. When the lecturer uses English, I can be accustomed to the use of English because he uses familiar and understandable English words. When my friends and I do not understand much about what he is talking about, he will translate it into Indonesian language. But, when we get what he means, he does not translate it into Indonesian language.

The data above showed that DA liked if the lecturer used English and Indonesian language in the teaching and learning process. DA could be accustomed to the use of English because the lecturer used familiar and understandable English words. When DA and his friends did not understand about the lecturer's explanation, the lecturer would translate it into Indonesian language. In contrast, when they understood what the lecturer was talking about, the lecturer did not translate anything into Indonesian language.

From the medium student's point of views (ET), the researcher got the data as follow.

I like if the lecturer does not use English fully. Sometimes he also needs to use Indonesian language because some students do not understand some vocabularies used by the lecturer. When the lecturer uses English, I can be accustomed to English daily vocabularies. I like the way Sir J speaks in English. Sir J often speaks English by using simple and understandable vocabularies. That's why I can understand what he is talking about. Then, I can also know more vocabularies.

The data above showed that ET liked if the lecturer used both English and Indonesian language during the teaching and learning process. When the lecturer used English in the classroom, it could make ET accustomed to English vocabularies. But sometimes, the lecturer 
also needed to use Indonesian language because some students still did not understand some vocabularies. From the high student's point of views (JE), the researcher got the data as follow.

I like if the lecturer uses both English and Indonesian language. He uses English in some aspects and Indonesian language in other aspects. But, if he wants to use full English, it does not matter. As a student, I can get accustomed more. My friends and I are able to know more how to pronounce words well so that we can be confident in speaking English. I think it's not a problem anymore because we study English. If the lecturer keeps using Indonesian language, it will be so weird.

Based on the data above, JE had different opinion from those two students. JE thought that the lecturer could use full English in the teaching and learning process. She and her friends could get more accustomed to the use of English vocabularies, know more how to pronounce words, and be confident in speaking English. In her opinion, it would be so weird if the lecturer kept using Indonesian language in the classroom.

Moreover, the researcher got the other data from the students' interviews about aspects of language instructions used by the lecturers in EAP classroom. From the low student's point of views (DA), the researcher got the data as follow.

In my opinion, I like when the lecturer explains the lesson like kinds of text and its language features by using English. I think it can make my friends and me getting accustomed to the use of English. I think the lecturer still can use Indonesian language in the classroom, but not for specific aspects. If the lecturer uses English and the students get what he is talking about, he does not need to translate it into Indonesian language. But, when the students get difficulties in understanding what the lecturer is talking about, he needs to translate it into Indonesian language. In the teaching and learning process, Sir J would like to explain the meanings of unfamiliar words in Indonesian language so that my friends and I can understand the meanings of those words. In teaching grammar, I prefer if the lecturer uses both English and Indonesian language with the percentage of $60 \%: 40 \%$. In talking informally with the students, Sir J often tells us some stories by using English and Indonesian language. So far, my friends and I enjoy and get what Sir J is talking about.

Based on the interview transcript, DA thought that the lecturer still could use Indonesian language in teaching and learning process, but not for specific aspects. When the students understood the lecturer's explanation in English, the lecturer did not need to translate it into Indonesian language. On the other hand, if the students got confused about what the lecturer was talking about, he needed to translate it into Indonesian language. In his opinion, the lecturer could use English to explain the lesson like kinds of text and its language features. It could make his friends and him getting more accustomed to the use of English. In explaining meanings, Sir J would switch unfamiliar English words into Indonesian language words. In 
chatting informally with the students, Sir J told the students some stories in English and Indonesian language. In teaching grammar, actually DA preferred if the lecturer used both English and Indonesian language with the percentage of 60\%: 40\%. From the medium student's point of view (ET), the researcher got the data as follow.

In my opinion, I like when the lecturer uses English in greeting the students, asking questions, giving activity instructions, closing the lesson, and others. Sir J often asks us to do the activities in the classroom like 'Okay, do the activities at page bla bla bla until page bla bla bla.' When he uses English in giving such instruction by using simple and understandable vocabularies, we can get understood and know more vocabularies. In teaching grammar and explaining the lessons like kinds of text - descriptive text, recount text, etc. - and its language features, I prefer if the lecturer uses both English and Indonesian language with the percentage of $50 \%: 50 \%$. If the lecturer only uses Indonesian language, we won't understand the English version. If the lecturer only uses English, we won't know the Indonesian version. In talking informally with the students, I prefer if the lecturer also uses both English and Indonesian language. If the lecturer uses English and Indonesian language, we can understand the stories that he is telling us and give some comments or feedbacks. If the lecturer only uses English in telling the stories, sometimes we don't understand the meanings of some English words.

The data above showed that ET thought that the lecturer could use English in greeting the students, asking questions, giving activity instructions, closing the lesson, and other aspects. When the lecturer used familiar and understandable English vocabularies, ET and her friends could understand easily what the lecturer meant. According to her opinion, the lecturer could use English and Indonesian language with the percentage of 50\%: 50\% to teach grammar and explain the lessons like kinds of text and its language features. Besides, the lecturer could use both English and Indonesian to talk informally with the students. From the high student's point of view (JE), the researcher got the data as follow.

In my opinion, I like when the lecturer uses English in all aspects, such as: greeting the students like 'how are you?', explaining the lessons like kinds of text and its language features, teaching grammar, closing the lesson, and others. I think it's not a problem to use English in the classroom because we study English. It will be so weird if the lecturer keeps using Indonesian language during the teaching and learning process. But, in some aspects like explaining meanings of unfamiliar words and talking informally with the students, the lecturer needs to use Indonesian language. In last meeting, we got the new English word 'inferred.' We did not understand what 'inferred' meant. Then, Sir J told us the meaning of 'inferred' in Indonesian language. I think it can help us to understand the meanings of unfamiliar words. In talking informally with the students, the lecturer needs to use both English and Indonesian language. If the lecturer only uses English in telling some stories, some students perhaps do not understand much about what he is talking about. But, during the teaching and learning process, Sir J 
always uses familiar and understandable vocabularies so that we do not get difficulties in understanding his stories.

Based on the interview transcript, JE had different opinion from those two students. In her opinion, the lecturer could use English in all aspects, such as: greeting the students, explaining the lesson, teaching grammar, closing the lesson, and others. JE thought that it would be so weird if the lecturer kept using Indonesian language in English teaching and learning process. In contrast, in some aspects like explaining meanings of unfamiliar words and chatting informally with the students, the lecturer could use both English and Indonesian language to help the students to understand more about what he was talking about.

\section{Discussion}

From the findings, most of the students agreed that the lecturers used English in some aspects to make them getting more accustomed to the use of English. If the lecturers keep using English in the classroom, the students can get more accustomed to the use of English. The students will be more familiar with English vocabularies, phrases, and sentences. It will help them to be enjoyable during the teaching and learning process. The effect of the use of English in educational context is that English is tended to be used as a medium of instruction in the classroom although the people use their local language (Vu \& Burns, 2014, p. 2). In addition, the lecturers' challenges to practice English as a medium of instruction (EMI) in the classroom are the students' English abilities and learning styles (Vu \& Burns, 2014, p. 21). Bear (1998a, 1998b) contended that English as a medium of instruction is an environment where the students have to communicate in English in the classroom because they do not have many opportunities to speak in English outside the classroom.

Furthermore, most of the students agreed that the lecturers could use Indonesian language for some aspects so that the students could understand more about what the lecturers were explaining about. When the lecturers also use Indonesia language during the teaching and learning process, it will help the students to understand more about the lesson. The use of the first language has a supportive role in teaching English as a foreign language (Zulfah, et al., 2015, p. 1281). The use of the first language is also one of the simplest strategies to make the students understand more about difficult expressions (Shin, 2006, p. 6). In addition, the use of the first language can make the students feel relaxed and avoid anxiety or confusion about English (Ford, 2009, p. 77). If the students do not use the first language as the language instruction, it will be difficult to know more about what the students know (Andrew, 2017, p. 3). 
Moreover, most of the students agreed that they got some benefits when the lecturers used both English and Indonesian language during the teaching and learning process. The use of English and first language has some points in EFL classroom. The suitable use of English and first language does not only give more language input to the students, but also motivate the students to learn English more (Zulfah, et al., 2015, p. 1281).

In the previous research, the study found that the participants mostly used English to dominate their approaches that was around $75 \%$ as the whole in the group. Besides, the participants used various techniques and strategies to help the students to understand more in the target language. One of them was by using the first language for the clearer comprehension, explanations, and instructions (Nilsson, 2013). This is quite in line with the results of this research which showed that the lecturers used the target and first language for some certain aspects in English teaching and learning process.

Furthermore, in another previous research, the study found that the participants showed an effort to use the target language in the teaching and learning process. Besides, the participants also used the first language to teach grammar and discipline the students (Miettinen, 2009). This is similar to the results of this study which showed that the lecturers used the target language for some aspects so that the students would be accustomed to the use of English. In addition, the lecturers used the first language to help the students to understand some materials that they did not understand in the target language.

Thus, the results of this research showed that the lecturers need to be able to use the target and first language in the appropriate conditions. This means that the lecturers should use English and Indonesian language in the suitable aspects. In learning English, the lecturers can use the first language to help the students to understand more about the materials so that the students can be motivated more to learn English.

\section{E. CONCLUSION}

The findings showed that the students could interact with the lecturer when the lecturer used both English and Indonesian language with good proportion during the teaching and learning process. In addition, the findings showed various results of the students' opinions related to appropriate aspects of language instructions used by the lecturers in EAP classrooms. In general, the students preferred if the lecturer used English to greet the students, ask questions, give activity instructions, and close the lesson. Besides, the lecturer could use English and Indonesian language in chatting with the students informally, 
explaining the lesson like kinds of text and its language features, teaching parts of grammar, and explaining meanings of unfamiliar words.

Thus, the use of language instructions is very essential in the language teaching and learning process. The lecturers need to know what aspects that should be used in the target language and what aspects that should be used in the first language. When the use of language instructions is appropriate, the students will get motivated more in learning English and the use of the first language can also help the students to learn English.

\section{REFERENCES}

Andrew, A. (2017). English medium instructions on English language proficiency. Asian Research Journal of Arts \& Social Sciences, 4(4), 1-10.

Bear, J. (1998a). To be a child in mother tongue: Education in foreign language. ed. A. Kilimci, 5355. Istanbul: Papirüs Yayinevi.

Bear, J. (1998b). To be a child in mother tongue: Education in foreign language. ed. A. Kilimci, 7376. Istanbul: Papirüs Yayinevi.

Chavez, A. (2016). Rights in Education and Self-Identity: Education and Language instructions in Namibia. International Education Studies, 9(3), 189-196.

Dickson, P. (1996). Using the target language. Slough, England: National Foundation for Educational Research.

Ewie, C. O. \& Eshun, E. S. (2015). The use of English as medium of instruction at the upper basic level (primary four to junior high school) in Ghana: From theory to practice. Journal of Education and Practice, 6(3), 72-82. Retrieved from https://eric.ed.gov/?journals

Ford. K. (2009). Principles and practices of L1/L2 use in the Japanese University EFL Classroom. JALT Journal, 31(1), 63-80.

Franklin, C. (1990). Teaching in the target language: Problems and prospects. The Language Learning Journal, 2(1), 20-24.

Kagwesage, A. M. (2013). Coping with English as language instructions in higher education in Rwanda. International Journal of Higher Education, 2(2), 1-12.

Nurpahmi, S. (2018a). Structured bilingual based instruction model in teaching English for specific purposes. Proceedings of INACELT (International Conference on English Language Teaching), 2(1), 111-118.

Nurpahmi, S. (2018b). The Effect of Bilingual Based Instruction in Teaching English for Academic Purposes.

Nurpahmi, S., Rahman, M. A., \& Salija, K. (2018). Bilingual-based Instruction in Teaching 
English for Academic Purposes at Islamic University. Journal of Language Teaching and Research, 9(3), 620-628.

Shin, J. K. (2006). Ten helpful ideas for teaching English to young learners. English Teaching Forum, (Online) Vol. (http://exchanges.state.gov/englishteaching/forum/archives/does/06-44-2-b.pdf, accessed on July, 2nd 2012).

Telli, G. (2014). The language instructions issue in Tanzania: Pertinent determining factors and perceptions of education stakeholders. Journal of Languages and Culture, 5(1), 9-16. Retrieved from http://www.academicjournals.org/JLC

Vu, N. T. T. \& Burns, A. (2014). English as a medium of instruction: Challenges for Vietnamese tertiary lecturers. The Journal of Asia TEFL, 11(3), 1-31.

Wolff, H. E. (2005). The Language Factor in Discourse on Development and Education in Africa. Paper presented at the Symposium on Language for Development in Africa, Moi University, Eldoret, Kenya, 1-3 June 2005.

Yin, R. K. (2014). Case study research: Design and methods ( $5^{\text {th }}$ ed.). Thousand Oaks, CA: Sage.

Zulfah, Rasyid, M. A., Rahman, M. A., \& Rahman, A. Q. (2015). Teachers' instructional and management talk in English foreign language classroom. Journal of Language Teaching and Research, 6(6), 1280-1288.

Zulfikar, T., Dahliana, S., \& Sari, R. A. (2019). An exploration of English students' attitude towards English learning. English Language Teaching Educational Journal, 2(1), 1-12. 